
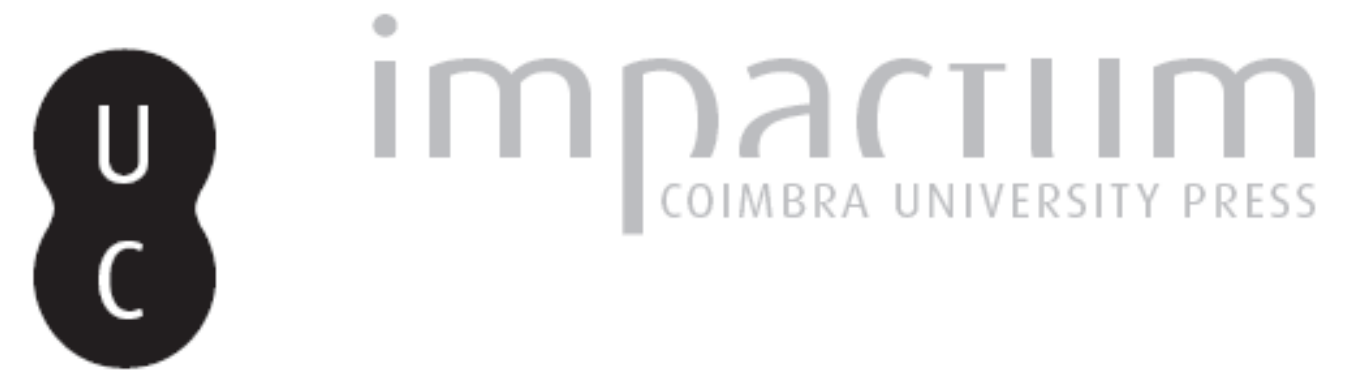

\title{
The fight against the least visible form of human trafficking:trafficking for labour exploitation
}

\author{
Autor(es): $\quad$ Puente Aba, Luz María
}

Publicado por: Imprensa da Universidade de Coimbra

URL persistente:

URI:http://hdl.handle.net/10316.2/43065

DOI:

DOI:https://doi.org/10.14195/1647-6336_17_6

Accessed : $\quad$ 26-Apr-2023 02:56:31

A navegação consulta e descarregamento dos títulos inseridos nas Bibliotecas Digitais UC Digitalis, UC Pombalina e UC Impactum, pressupõem a aceitação plena e sem reservas dos Termos e Condições de Uso destas Bibliotecas Digitais, disponíveis em https://digitalis.uc.pt/pt-pt/termos.

Conforme exposto nos referidos Termos e Condições de Uso, o descarregamento de títulos de acesso restrito requer uma licença válida de autorização devendo o utilizador aceder ao(s) documento(s) a partir de um endereço de IP da instituição detentora da supramencionada licença.

Ao utilizador é apenas permitido o descarregamento para uso pessoal, pelo que o emprego do(s) título(s) descarregado(s) para outro fim, designadamente comercial, carece de autorização do respetivo autor ou editor da obra.

Na medida em que todas as obras da UC Digitalis se encontram protegidas pelo Código do Direito de Autor e Direitos Conexos e demais legislação aplicável, toda a cópia, parcial ou total, deste documento, nos casos em que é legalmente admitida, deverá conter ou fazer-se acompanhar por este aviso.

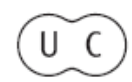




\section{DEBATER \\ A EUROPA}

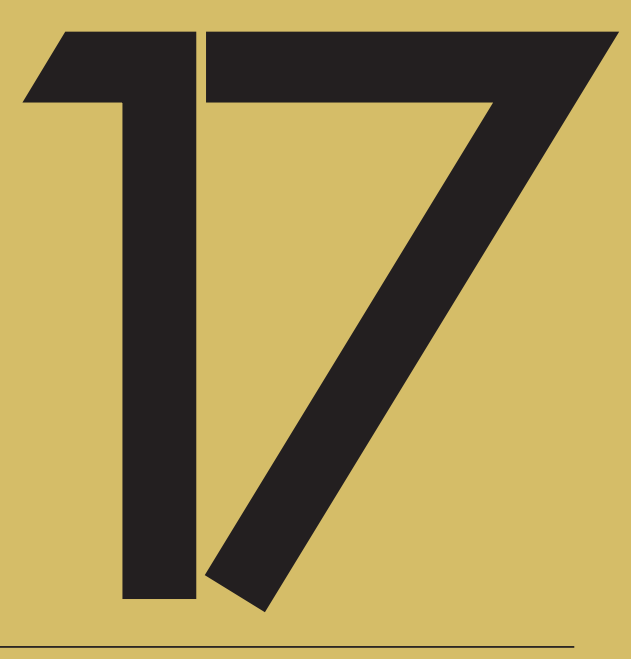

jul-dez 2017

UNIÃO EUROPEIA E O COMBATE AO
TRÁFICO DE SERES HUMANOS

THE EUROPEAN UNION AND COMBATING

TRAFFICKING IN HUMAN BEINGS 


\title{
The fight against the least visible form of human trafficking: trafficking for labour exploitation ${ }^{22}$
}

\author{
Luz María Puente Aba, $\mathrm{PhD}$ \\ University of A Coruña, Spain \\ E-mail: lpuente@udc.es
}

\begin{abstract}
The least visible of human trafficking is the one that is carried out for labour exploitation purposes. The aim here is to focus on two different needs: first, finding an accurate definition of forced labour, that encompass controversial questions, such as the meaning of clauses as "coercion" and "abuse of a position of vulnerability", and the difference between human trafficking for the purpose of labour exploitation and forced labour; and second, identifying causes of human trafficking for labour exploitation. The article tries to put forward proposals regarding the best way of making these phenomena more visible and effectively combating them.
\end{abstract}

Keywords: Human trafficking for labour exploitation; forced labour; causes of human trafficking; abuse of a position of vulnerability; coercion.

\section{The need to focus on trafficking for labour exploitation}

The Protocol to prevent, suppress and punish trafficking in persons, especially women and children, supplementing the United Nations Convention against transnational organized crime (Palermo, 2000), clearly defines the "trafficking in persons" as "the recruitment, transportation, transfer, harbouring or receipt of persons, by means of the threat or use of force or other forms of coercion, of abduction, of fraud, of deception, of the abuse of power or of a position of vulnerability or of the giving or receiving of payments or benefits to achieve the consent of a person having control over another person, for the purpose of exploitation. Exploitation shall include, at a minimum, the exploitation of the prostitution of others or other forms of sexual exploitation, forced labour or services,

22 This paper has been produced within the Research project founded by the Spanish Ministry of Economy and the European Regional Development Fund (DER2015-65411-R), whose main researcher is Luz María Puente Aba. 
slavery or practices similar to slavery, servitude or the removal of organs". This is the same definition that is used by the Council of Europe Convention on action against trafficking in human beings (Warsaw, 2005), and practically the same as the one provided in Directive 2011/36/EU of the European Parliament and of the Council of 5 April 2011, on preventing and combating trafficking in human beings and protecting its victims, and replacing Council Framework Decision 2002/629/JHA.

Despite the fact the purpose of exploitation in the phenomenon of trafficking can encompass a great variety of exploitative situations, some of which are presented as a mere example in the United Nations (UN) Trafficking Protocol, traditionally trafficking for sexual exploitation has been the centre of attention. This can be seen generally in documents and action plans against human trafficking, both at a national and international level; in fact, the UN recognised in 2008 that study and research on trafficking for labour exploitation was still "in its infancy" (UNODC 2008, p. 5). At an international level, the fundamental effort in the fight against forced labour has been made by the International Labour Organization (ILO). The publication of its Global estimate for forced labour must be outlined, the last edition of which was in 2012, together with other documents that intend to clarify some concepts on this topic and to implement action plans to fight against this form of exploitation (e.g. ILO 2005, 2008, 2012).

The UN admits that the over - representation of sexual exploitation may be the result of statistical bias, taking into account that sexual exploitation tends to be more visible (in city centres or along highways, while victims of forced labour often work in hidden locations; Defensor del Pueblo 2012, p. 271), and to be more frequently reported. Another element to take into account is that, until recently, many countries did not include forced labour as a purpose of the crime of trafficking in human beings. And due to these reasons, and as also happens with human trafficking in general, the number of prosecutions and convictions for human trafficking for labour exploitation has been so far very low (ILO 2013).

Nevertheless, in recent times this situation has changed, if we consider the latest statistics: according to the data provided in the UN Global report on trafficking in persons in 2009, sexual exploitation was the most commonly identified form of human trafficking (79\%), followed by forced labour (18\%); but this Global report in its 2012 edition affirms that trafficking for the purpose of sexual exploitation accounts for $58 \%$ of all trafficking cases, while trafficking for forced labour represents 36\%, recognizing that the proportion of detected cases of this last kind of trafficking has doubled in the period 2009-2012. In this Report it is also indicated that trafficking for other forms of exploitation accounts for a 6\%; among these other forms the Report cites child begging or the use of children to commit petty crimes or to be combatants, illegal adoptions, forced marriages, production of pornographic material or the trading of body parts for rituals or traditional healing; here mixed forms of exploitation are also included. The Global report of 2014 shows that trafficking for sexual exploitation represents $53 \%$ of all cases, forced labour $40 \%$, organ 
removal $0.3 \%$, and there is a $7 \%$ of other different forms of exploitation, identified in this Report as the following: mixed exploitation (sexual exploitation and forced labour), committing crimes, begging, pornography, forced marriages, benefit fraud (fraudulent state benefit claims), baby selling, illegal adoption, armed combat and rituals. Finally, the last Global report of 2016 offers the following updated figures: 54\% trafficking for sexual exploitation, 38\% trafficking for forced labour, and $8 \%$ trafficking for other forms of exploitation. One possible reason for this bias can be the fact that, according to UN data (Global report of 2012), sexual exploitation is more common in Europe, Central Asia and America, whereas forced labour is more frequently detected in Africa, the Middle East and South and East Asia, and it should be taken into account that European countries are the ones that detect more victims of trafficking in human beings; so, exploitation patterns prominent in Europe may be disproportionately reflected in global totals. Furthermore, these figures of forced labour do not really mean that the cases of this form of exploitation have increased; considering that forced labour has been included recently in the crime of human trafficking in many countries, these numbers probably show an enhanced capacity of detection rather than a real rise in the crime. Anyway, according to the Global reports of 2014 and 2016, the increasing detections of trafficking for forced labour has been a significant trend in recent years.

One of the problems that has been highlighted in a recurrent way by those who study human trafficking consists of the difficulty of offering exact numbers about the scale of this problem, fundamentally about the number of victims or presumed victims of this global phenomenon (IOM 2008, Nelken 2010, pp. 484 ff., Goodey 2012). Not even official data can be totally reliable; as Nelken highlights (pp. $484 \mathrm{ff}$.), it is revealing that the number of convictions is very low, owing to the difficulty in discovering this crime; and on the contrary statistics could include cases that are not really part of the definition of human trafficking: as Gallagher (2010, p. 377) and Wade (2012, p. 161) point out, prosecuting for related offences rather than for trafficking may be easier and appealing in the short term ${ }^{23}$.

Without analysing which could be the main factors that lead to this situation, it is interesting to point out some curious data in relation to the most recent reports and statistics regarding human trafficking. The ILO Global estimate of forced labour from 2012 put the specific figure of 20.9 million people as victims of forced labour globally, whereas the UN Global report on trafficking in persons in the same year is focused on showing trafficking flows and patterns, offering essentially qualitative percentages (e.g. of forms of trafficking, or of gender and nationality of victims), but acknowledging the difficulties in measuring exactly the scale

23 GALLAGHER says (GALLAGHER, Ann - The international Law of human trafficking. New York: Cambridge University Press, 2010. 535 p. ISBN 97805211910742010, p. 377) that this could have a number of potentially significant long term consequences that should be taken into consideration: for example, a trafficking charge may trigger an entitlement on the part of victims to secure access to support services, protection and assistance (v.gr. a reflection period and temporary or even permanent residence status in the destination country) that would not otherwise be available. 
and number of victims of human trafficking. It must be highlighted that in 2013 the first report at the European Union level was published on the statistics on trafficking in human beings (EUROSTAT 2013), offering specific statistics and numbers, but as the report itself recognises, the data were collected from different authorities working in this field, and more "meta-data" and better identification procedures could improve the real estimation of this phenomenon. On the contrary, what has been commonly addressed and agreed is the kind of sectors more susceptible to harbour forced labour: according to the estimations of the UN (2008, pp. 3-4), these sectors are agriculture, food processing, construction, textile and garment enterprises, retail, manufacturing, logging, mining, restaurants, domestic work and entertainment (Coster van Voorhout 2007, pp. 48-49). In reality, the more probable fields where forced labour can be found are those industries that rely on cheap or seasonal labour, or involve difficult and dangerous jobs, and above all in industries with complex chains of subcontracting, because this way of recruitment favours the concealment of this kind of labour.

It is interesting to note that sexual work or prostitution has not been mentioned among the sectors the UN identify as susceptible to developing forced labour. As we have seen, the definition of human trafficking in the UN Trafficking Protocol, and also the documents, legislations and reports on it, distinguish trafficking for sexual exploitation and for forced labour. In this way, when the victim is coerced to be a sex worker, this situation is considered as trafficking for the purpose of sexual exploitation but, could it not really be considered as forced labour? In fact, it should be taken into account that in some countries prostitution is regulated as a legal job (Kane 2013, pp. 124-125). It is remarkable to note that there are documents that take this work into account as forced labour, when it takes place under coercion: this is the case of the aforementioned ILO Global estimate of forced labour (2012): it says that within the global estimate of 20.9 million people victims of forced labour, 18.7 million (90\%) are exploited in the private economy, by individuals or enterprises; out of these, 4.5 million (22\%) are victims of forced sexual exploitation, and 14.2 million (68\%) are victims of forced labour exploitation in economic activities, such as agriculture, construction, domestic work or manufacturing; the remaining 2.2 million (10\%) are in state-imposed forms of forced labour, for example in prisons, or in work imposed by the state military or by rebel armed forces. The ILO itself has clarified that coercive sexual exploitation comes within the scope of the definition of forced labour (ILO 2005, 2007, 2012). The question here is that the UN Protocol considers forced labour as one form of trafficking in persons among other forms of exploitation; whereas, for ILO human trafficking is one of the possible forms to accomplish forced labour.

Finally, focusing on the Spanish case, even though there is now in our Criminal Code a specific crime of trafficking in human beings (art. 177 bis) that follows the UN Trafficking Protocol, the centre of attention of the Spanish authorities has been human trafficking for sexual exploitation, and this is shown in the implementation of the National Action Plan 
to combat trafficking in human beings for sexual exploitation (2009-2012), followed by a new Plan in this same field for the period 2015-2018. As it is highlighted in the Report concerning the implementation of the Council of Europe Convention on Action against Trafficking in Human Beings by Spain, produced in 2013 by the Group of Experts on Action against Trafficking in Human Beings (GRETA) of the Council of Europe, the action to combat human trafficking should address victims of all forms of exploitation, through a comprehensive National Action Plan against trafficking in human beings; specifically, GRETA highlights the need to raise awareness of trafficking for the purpose of labour exploitation. This same conclusion can be found in the Report produced by the Spanish Ombudsman in relation to human trafficking, that also observes the lack of data on the real dimension of trafficking in human beings (Defensor del Pueblo 2012).

Starting from these initial considerations and recognising the need to move the focus to human trafficking for the purpose of labour exploitation, two specific needs will be dealt with here in order to better address this form of trafficking: the need for an accurate definition of forced labour, which includes the distinction between forced labour and trafficking for labour exploitation, tackling the question of the real meaning of some controversial terms like "coercion" and "abuse of a position of vulnerability", and the need to identify the root causes of human trafficking for labour exploitation. As a result of this, some conclusions will be drawn to suggest the best perspective to address human trafficking for the purpose of labour exploitation.

\section{First need: an accurate definition of forced labour}

The definition of forced labour and the question of consent: the meaning of coercion

Forced labour is defined in the ILO Forced Labour Convention (No. 29) that dates back to 1930 . The term covers all work or service that any woman, man or child is coerced to do under the threat of a penalty, and for which they have not offered themselves voluntarily.

First of all, there is a problem that has been pointed out in different studies on human trafficking for labour exploitation: the fact that many victims have difficulties or refuse to notice their condition as alleged victims of exploitation. It has been said that the lack of awareness of one's labour rights and the situation of necessity that may exist (ACCEM 2008, p. 90), and the fact of having worked in exploitative conditions in countries of origin (Plant 2011, p. 9), could be obstacles preventing victims from feeling they are being exploited, and this can then throw the reality and authenticity of the workers' consent into question. But this should not lead to the conclusion that these alleged victims are unable to appreciate their own position; as Olsen indicates (2008, p. 36), it cannot be overlooked that the concepts themselves of "exploitation", "coercion" and "consent" could have a different sense according to each culture and society, and that it is also 
important to consider the context and circumstances of every person, because they can have influence on the authenticity of one's own choice (Puente 2011, 141-142). Victims may have mixed feelings about their situation, even considering it better than living in their own countries (Nelken 2010, p. 483). Sometimes exploitative conditions of migrants can be attributed to a conscious choice of so-called "self-exploitation" rather than to coercion, willingly submitting themselves to severe conditions in order to get money to pay their debts (Ceccagno et al. 2010, p. 133). Anyway, the fact that the exploitative situation could be preferable to the severe poverty in the places of origin should not make the violation of workers' rights invisible (Montero 2012).

The ILO document Human trafficking and forced labour exploitation. Guidelines for legislation and law enforcement (2005) tries to show some situations where coercion can be recognised, regarding the concept of forced labour: physical or sexual violence, restriction of movement of the worker, debt bondage, withholding wages or refusing to pay the worker at all, retention of passports and identity documents, and threat of denunciation to the authorities. Mere wage disputes do not mean real coercion whenever the worker is free to leave the job, although it is sometimes a difficult decision when there is no certainty to find a new job or even to have money enough to survive (Smith and Kangaspunta 2012). It is important, to define coercion, to take into account whether the individual has any legitimate alternative to support his/her basic needs; Burke (2013, p. 5) concludes that desperation to perform responsibilities such as support a child, and feed and keep one's self safe, can be a form of coercion. Olsen (2008, p. 22) also points out that the pressure of the threat of a penalty could come not directly from the employer, but from external circumstances (he presents the case of Chinese workers in the United Kingdom that have decided freely to get involved in sweated labour, but under pressure from their debts and creditors in China, not really from the employer, who had employed them anyway in unacceptable conditions).While this is true, one can agree that subjecting workers to illicit conditions such as excess of working hours, lack of rest or insufficient salary, among other violations of workers' rights, cannot be considered as a form of forced labour if the element of coercion is lacking, that is to say, if the worker is free to leave that job and get rid of this situation (Pomares 2013, p. 136).

As Maqueda (2009, pp. 132-133) reveals, a tendency can be observed to distort the real significance and definitions of these concepts. She points out the Recommendation R (2000) 11, from the Committee of Ministers of the Council of Europe on action against trafficking in human beings for the purpose of sexual exploitation, and its Explanatory memorandum, that acknowledges that "coercion" can include, among other situations, the abuse of a position of vulnerability, for instance due to an illegal or precarious administrative situation. As she states, this represents the risk of extending the definition of trafficking to migrations that are really consented, even though the person is in a difficult legal position. It is also remarkable that the ILO Special Action Programme to combat Forced Labour 
(2013b) mentions, among the indicators of coercion in the definition of forced labour, the "abuse of a position of vulnerability", situation that had not been included in the aforementioned ILO document in 2005.

The difference between human trafficking for the purpose of labour exploitation and forced labour. Again the question of consent: the meaning of abuse of a position of vulnerability

It must be highlighted that a difference has to be drawn between "human trafficking for the purpose of labour exploitation" and "labour exploitation" or "forced labour" itself.

According to the definitions and considerations by ILO, both terms are not synonymous, being "forced labour" a wider and more comprehensive concept than "human trafficking for labour exploitation" (ILO 2008). Certainly, both terms cannot be considered synonymous since the essentials of "trafficking" constitute a "process", where we can distinguish three stages: recruitment, transportation and exploitation, as for example the UN indicates (UNODC 2006; see also Coster van Voorhout 2007, 65 ff., Olsen 2008, p. 13, Villacampa 2011, pp. 57 ff.); in this last stage one can find different forms of exploitation, forced labour being one among them. But trafficking does not require the presence of an exploitative situation, it only implies the "purpose of exploitation"; in this way, trafficking should not be identified with the situation of exploitation that derives from the process of trafficking itself. As it is said, trafficking is a process that ends with the effective recruitment of the victim and the transportation to the place where he/she is going to be exploited (Bales / Trodd / Williamson cited Villacampa 2011, pp. 57 ff.). So, movement is an essential element of trafficking, regardless of the extent of this movement, whereas forced labour is a typical outcome of trafficking, and occurs at the point of exploitation. Victims of forced labour may have migrated willingly, and after they can have entered into this kind of coercion; there can also be victims of forced labour in the same place where they live (Kane 2013, pp. 118-119).

Although human trafficking includes a stage of transportation, this does not necessarily mean crossing national borders, because victims can be recruited and exploited in one country. Actually, the aforementioned UN Global report on trafficking in persons (2009 edition) highlights that most trafficking is national or regional, carried out by people whose nationality is the same as that of their victims, even though there are also notable cases of long - distance trafficking (also UNODC 2006, p. 52). Specifically, the Global report of 2012 affirms that domestic trafficking (that is to say, trafficking within the same country) accounts for more than $25 \%$ of the total number of victims detected globally, and that in recent years an increasing number of cases of domestic trafficking has been detected and reported (there was an increase from 19\% in 2007 to $31 \%$ in 2010) (see also ILO 2005, Gallagher 2010, p. 47, Plant 2011, p. 9, Villacampa 2011, p. 38, Montero 2012, Burke 2013, p. 5, Kane 2013). 
According to the definition of the UN Protocol, human trafficking needs the presence of three elements: act, means and purpose; synthetically, this means that the recruitment and transportation of the person has to be made by different means that are always tantamount to a lack of real consent, with the purpose of some form of exploitation (UNODC 2006, Smith and Kangaspunta 2012, p. 26). One of the "means" inherent to human trafficking consists of the "abuse of a position of vulnerability". This is really a term hard to define; as the UN itself highlights (UNODC 2013), there is the need to clearly determine the limits of the concept of "vulnerability", and also to ascertain if this situation has really been the object of abuse (see Malpani 2010, pp. 140 ff.).

The UN refers to the significance of the term "vulnerability" in its document $A n$ introduction to human trafficking: vulnerability, impact and action (UNODC 2008b). According to this document, the "Travaux préparatoires" to the Trafficking Protocol indicate that the reference to the abuse of a position of vulnerability is understood to refer to any situation in which the person has no real and acceptable alternative but to submit to the abuse involved, so it would be possible to state that the individuals most vulnerable to harm are those with the fewest alternatives (Gallagher 2010). Taking this as a basis, the UN document introduces a new definition of vulnerability, as "a condition resulting from how individuals negatively experience the complex interaction of social, cultural, economic, political and environmental factors that create the context for their communities". In this way, conditions of vulnerability are usually the results of political, social, cultural or economic practices and policies that fail to ensure equal access and protection to all members of a society. There is not a total agreement on the conditions that lead to vulnerability to human trafficking, and the UN tries to indicate some of them: being a child; gender; poverty; social and cultural exclusion (e.g. marginalization due to ethnic, linguistic and religious differences, or low social status); limited access to education; political instability, war and conflict; social, cultural and legal frameworks (e.g. discriminatory labour practices, patriarchal structures, or early or forced marriage); movement (e.g. being a refugee or an asylum seeker) and demand (that is to say, the benefits inherent to the trafficking chain).

Regarding human trafficking for labour exploitation, sometimes it can be complicated to establish if there has been real abuse of a position of vulnerability. According to the UN (2008) and the ILO (2012), people who are under some form of economic compulsion to accept sub-standard working conditions because they simply have no alternative are considered as victims of exploitation or of abuse of vulnerability, taking into account that victims of forced labour are those ones who undertake a job against their will. The UN has paid special attention to the real significance of this "abuse of a position of vulnerability" in its Issue paper Abuse of a position of vulnerability and other "means" within the definition of trafficking in persons (2013). This document points out the difficulty to draw a borderline between real consent and abuse of a position of vulnerability: does the 
victim's vulnerability really nullify the apparent consent, or can a meaningful consent really exist when the person is in this specific position? That is a very important question, because depending on how we interpret the statements of the person involved, we could accept or deny his/her condition as a victim of human trafficking.

In its Operational indicators of trafficking in human beings, the ILO (2009) presents some circumstances than could indicate the presence of this abuse of a position of vulnerability: e.g. abuse of a difficult family situation, abuse of illegal status, economic reasons, personal situation, or relationship with authorities / legal status. Nevertheless, some of these criteria are too vague: for example, what could some of these terms really mean, like "economic reasons" or "personal situation"? Could or should some situations like poverty or absence of alternative employment opportunities be included here? We can find a clear explanation in some other documents from the ILO: Global estimate of forced labour (Executive summary, 2012, and Results and methodology, 2012) and Hard to see, harder to count. Survey guidelines to estimate forced labour of adults and children (2012): as it is said here, the ILO estimates that 20.9 million people are victims of forced labour globally, "trapped in jobs into which they were coerced or deceived and which they cannot leave". So the distinctive note of forced labour could be placed in the real impossibility to leave the job, a situation that is not really present in cases where people are "forced" to accept some jobs because of their position of vulnerability, but they have the "physical" possibility of giving it up. A job would only be undertaken involuntarily when the person either became engaged in the activity against his/ her free will or, once engaged, finds that he/she has to do tasks that are not part of what was agreed at the time of recruitment and cannot leave the job.

\section{Second need: identifying causes of human trafficking for labour exploitation}

As some documents from the UN show (2008, pp. $5 \mathrm{ff}$.), the existence of human trafficking for labour exploitation is possible due to an unsatisfactory labour legislation in some countries, and to the lack of real control of labour conditions, even in States that have an acceptable standard of protection in this field; anyway, a deeper reflection should be made on the root causes of this phenomenon, that is to say, why is labour exploitation necessary or profitable?

First of all, a traditional argument has been the existence of economic difficulties as an important factor for trafficking in human beings. The systematization of flows and trends in human trafficking around the world seem to confirm that, in many cases, trafficking is influenced by economic factors. Nevertheless, this reason alone cannot be used to explain such a serious phenomenon which occurs globally and in very different forms (UNODC 2012).

The general and vague reference to economic difficulties should be explained in the context of socioeconomic inequality stemming from the current society as a result 
after the era of colonization and the new economic globalization. On one hand, the geographic and social context left by the colonization era has caused great problems such as poverty, inequality and a lack of social support networks. On the other hand, the development of capitalism and globalization is exclusive by definition, fomenting clear inequalities and leaving behind those who cannot access economic resources. On this basis, abuse can be defined as wealthy people or countries that, in order to achieve their welfare goals, or their objective to maximize profits, employ human beings as workforce (Bales 2000 cited Villacampa 2011, pp. 86 ff, Sanghera 2005, p. 7, Kaye and Winterdyk 2012, García Vázquez 2012, p. 16, Aboso 2013, pp. 31 ff.). In order to reduce costs and simultaneously satisfy the great demand of goods in the industrialised world, big enterprises have turned to "offshoring", that is to say, moving their manufacturing centres to countries with a lower standard of living and salaries, and with poor labour protection. This phenomenon is favoured by the economic and social differences between people from different areas in the continent, with the vulnerable population (in terms of poverty and social consideration, mainly) being more susceptible to being exploited and becoming victims of human trafficking (Cottingham et al. 2013, pp. 53 ff., Turek 2013, pp. 74 ff.).

Anyway, the impact of globalization must not be understood only in economic terms, but also in other terms: it has been argued that, even though globalization favours the flow of people and goods throughout the world, simultaneously the States are heightening their own security with the unavoidable restrictions in terms of citizenship or of foreigners or migrants' rights; this could be indeed a gap in the fight against human trafficking (Kaye and Winterdyk 2012). Finally, it cannot be overlooked that these profound economic changes have also had an influence on the modification of social structures. As Bales pointed out (2000, p. 246), the consolidation of industrial agriculture, the urban development and the growth of big enterprises have determined the concentration of wealth in determined people and places, and this leads to the gradual disappearance of subsistence economies with their own social structures, that empowered individuals and small communities to earn their own livelihood by creating local support networks.

The same objective of cost cutbacks is pursued by States, and this can explain the increasingly lower level of visibility and existence of control institutions in the labour market. Moreover, due to the phenomenon of "offshoring", it is possible to concentrate labour activities in States that apply limited control in this field; besides, this long chain of the production system of goods favours the proliferation of private entities to intermediate in labour contracts, with a lack of transparency that facilitates human trafficking for labour exploitation. Precisely the EU strategy towards the eradication of trafficking in human beings 2012-2016 points out the need to specifically target trafficking for labour exploitation, and this would mean several measures, for example focusing on the administrative aspects of trafficking such as on contractors and subcontractors and job recruitment agencies; this 
would include developing a best practice guide for public authorities on the monitoring and enforcement of temporary work agencies and intermediary agencies, considering licensing systems and work related to the liability of such agencies (see Belser and Andrees 2010, pp. 3-4). It must be taken into account that difficulties in labour control are even more evident in the case of non-regulated jobs, fundamentally prostitution, or in relation to work that is often part of the black economy, like domestic and care work.

The consolidation of our current consumer society is of great relevance, where we find a growing demand of all kinds of cheap goods and services; this has stimulated competition among enterprises that seek to satisfy this demand by reducing workforce costs, favouring the already mentioned "offshoring", so that manufacturing centres are allocated in countries with a lower standard of living and unsatisfactory labour provisions, leading to abuse of subcontracting in some phases of its production process (Turek 2013, 83-85). Reproducing the words of Moe-Lobeda cited by Turek (Moe-Lobeda 2002 cited Turek 2013), "we do not wish to buy shirts made in sweatshops [...] yet, we do". This should be interpreted as the lack of visibility and consciousness about the real importance of human trafficking, exacerbated by the conditions inherent to globalization.

In the end, it is a conglomerate of factors that favours or explains human trafficking for labour exploitation, and that can be singled out for different kinds of labour exploitation. For instance, the questions of globalization, "offshoring" and the development of our consumer society can be identified as the main factors to explain forced labour in industry sectors (garments, and manufactured goods in general). However, reasons may vary in other kinds of forced labour; for example, trafficking for domestic and care work: even though starting from poverty as a general "push factor" for all kinds of trafficking, here we can appreciate a clear gender bias, and we can point out as explanatory factors the globalization of women's work, especially of high and upper- middle class women, accompanied by the failure of industrialized States of societies to tackle with the question of domestic and care work, that is to say, the lack of real public help, and the hardly visible changes in the role of men in regard to these tasks (Ehrenreich and Hochschild 2002).

It is important to point out here that one of the strategies posed by several documents and action plans against human trafficking is focused on understanding and reducing demand for all forms of trafficking (e.g. The EU strategy towards the eradication of trafficking in human beings, 2012-2016). That would mean the execution of public awareness campaigns targeting consumers, with the objective of reducing the demand and supply of services and goods by victims of trafficking in human beings. This aim has been considered and implemented in some legislations in relation to trafficking for sexual exploitation, through the criminalization of the client who asks for sexual services. It must be recognized that the Trafficking Protocol does not pronounce directly on whether the use of services of victims of trafficking should be criminalized, only establishing that States Parties shall adopt measures to discourage demand that fosters all forms of exploitation (art. 9); on the 
contrary the European Trafficking Convention, even though it states in its article 6 similar considerations in order to discourage demand, in its article 19 requires States parties to consider criminalizing "the use of services which are the object of [trafficking - related] exploitation [...] with the knowledge that the person is a victim of trafficking in human beings", but it is only a requirement to "consider" adopting such measures (Gallagher 2010, p. 378). It should be required that the person knows or recklessly disregards the fact that the good or service comes from a victim of human trafficking; being this indeed a complex question, it could be based on objective circumstantial evidence.

The specific question of criminalization has been addressed in some documents from these international organizations. The Legislative Guides produced by the UN for the implementation of the Trafficking Protocol (UNODC 2004, p. 297) declare that demand reduction "could be achieved in part through legislative or other measures targeting those who knowingly use or take advantage of the services of victims of exploitation". More specifically, the Model Law against trafficking in persons (UNODC 2009) declares in the commentary to its article 11 that, in addition to awareness - raising campaigns to discourage demand, "the use of the services of a victim of trafficking and / or forced labour or services may be penalized in order to deter 'users' of services of trafficked victims". We can refer back to article 19 of the European Trafficking Convention here, that requires the States Parties to consider the option of criminalising demand. The recent Resolution 1983 of the Council of Europe (8/4/2014) can also be cited, where the Parliamentary Assembly calls on Council member and observer States, to consider criminalising the purchase of sexual services, as the most effective tool for preventing and combating trafficking in human beings.

Nevertheless, in practice this kind of action is being dealt with in some States regarding sexual work, but it has not been implemented with regard to consumers of goods or services made by victims of labour exploitation (e.g. garments or almost any kind of object in the market). It is true that there are many initiatives in this field, not only directly from enterprises but also from institutional bodies (e.g. UN Global Compact) ${ }^{24}$, so that some enterprises declare to be committed to producing and distributing goods and services guaranteeing the respect of human rights and avoiding forced labour. Besides the fact that this is no legislative measure, one can doubt the real objective (respecting human rights and laws or improving one's reputation?) and the veracity of some of these initiatives ${ }^{25}$.

24 As it is defined on its website (www.globalcompact.org), the UN Global Compact is a strategic policy initiative for businesses that are committed to aligning their operations and strategies with ten universally accepted principles in the areas of human rights, labour, environment and anti-corruption. Business and non-business entities are encouraged by the UN to participate in this initiative.

25 For example, in 2011 Bloomberg News published a report about child labour in Burkina Faso, where children picked cotton allegedly for a firm who expressly declared it respected human rights and avoided child labour: see for example the websites of Bloomberg and of COMBAT, the EU DAPHNE funded project for prevention, protection and support against trafficking (combattraficking.eu). 
As Gallagher (2010, pp. 433-434) clearly explains, the question of demand is a very delicate issue because it could involve moral considerations and because it really contains different aspects that should be clarified. On one hand, tackling demand could be the expression of ideological considerations: one clear example could be the aim of prohibiting prostitution completely; on the other hand, addressing demand could be totally refused just like the rejection of these ideological positions. In order to act appropriately on demand, there is the need to distinguish between the causes or factors that shape demand and the demand itself; that is to say, the aim should not only be the individuals that demand goods or services coming from victims of human trafficking, but should also pay attention to the way in which States construct conditions that make it possible or profitable to consume these goods or services. Focusing on forced labour, it is evident that if the economic institutions benefit from this kind of labour, they will facilitate, for example through liberal regulatory frameworks, or at least will not avoid, the flow and development of these hidden activities. And finally, it should be reflected whether the abundance of supply could be a way to generate demand, or at least a great deal of demand. So, the States have an important role to play in reducing demand, not criminalizing as the only resource, but through other measures like fighting against the discrimination that leads people to consider other persons as inferior and susceptible to being abused, or like implementing really protective laws and policies that could guarantee the rights of workers, migrants and more sensitive groups (Gallagher 2010, pp. 438-440) ${ }^{26}$.

Even with the criminalisation of demand being an option for State legislators, we would face a complicated question: what does "demand" really mean, taking into account the multiple forms and purposes of human trafficking? And what about sectors where it is difficult to find a "demand-side of trafficking" (e.g. begging, committing crimes)? As O'Connell (2012) points out, there is not a clear and straightforward direction between offer and demand; that is to say, boycotting one good or service coming from human trafficking is not really effective: "it would be difficult to ask consumers to abstain completely from the use of all the goods, services and practices that may be associated with "trafficking" until such time as "trafficking" is abolished partly because of the length of the list of products and services concerned, and its overlaps with markets and practices that are viewed as socially desirable". Individual consumers cannot really put an end to forced labour by avoiding buying goods or services coming from human trafficking. In reality, forced labour is not simply a result of global consumer demand for cheap goods, because this kind of offer is sometimes promoted by governmental policies that favour precarious and sweated

26 Gallagher (2010, pp. 441-442) concludes that there is no normative duty to criminalise demand of goods or services deriving from victims of human trafficking, but says that "however, such criminalization addresses a critical link in the trafficking chain and could be considered a key aspect of a comprehensive strategy to address demand for the goods and services produced through the exploitation of trafficked persons". 
labour in non- industrialized countries ${ }^{27}$. According to this author, dominant discourse on "trafficking as modern slavery" distorts perceptions of what is possibly the most significant aspect of "the demand-side of trafficking", namely the demand for opportunities to migrate. She considers the idea of educating people in "sending" countries about the horrors of trafficking/slavery, so that they will be wary of those who try to lure them into the trap of travelling abroad, rather than to think how to make migration safer; talking of "trafficking as modern slavery" has actually lent legitimacy to states' efforts to strengthen border controls and restrict immigration in ways that make many groups of migrants more vulnerable to a range of human rights violations.

\section{Conclusions}

As a sort of conclusion, one can start from the fact that human trafficking for the purpose of labour exploitation has been generally underestimated in the fight against trafficking in human beings, even though in recent times this same fact has been shown through different international documents, especially from the ILO. The definition of trafficking offered by Kempadoo, Sanghera and Pattanaik (2005, also Desyllas 2007) is illustrative, "as the trade and exploitation of labor under conditions of coercion and force", trying in this way to bring to light not only that human trafficking has other purposes beyond sexual exploitation, but also that many situations of exploitation, including the sexual one, can really be included in the broader concept of forced labour or services (see also Burke 2013, pp. 6-7).

Some of the main problems or challenges of correctly addressing the question of trafficking for labour exploitation can be outlined here.

First of all, it is necessary to start with a clear definition of "forced labour". According to the UN definition of human trafficking, the purpose of exploitation shall include "forced labour or services, slavery or practices similar to slavery, and servitude", terms that refer to the purpose of labour exploitation. The definition offered in the ILO Forced Labour Convention is generally accepted, with forced labour being "all work or service that any woman, man or child is coerced to do under the threat of a penalty, and for which they have not offered themselves voluntarily". In reality, it is a definition broad enough to cover the other terms mentioned in the UN Trafficking Protocol (slavery, practices similar to slavery and servitude), because the core of this concept is the existence of control over another person, who is coerced to do a job or service against her/his will. Slavery and servitude should also be understood in this way, taking into account that contemporary slavery does not suppose the legal property of one person, but the factual control over him/her (Bales 2000, pp. 6-7). The objective of this

27 O'Donnell (2007, p. 9) presents as an example the case of US government subsidies to domestic cotton producers that artificially deflate the price of cotton worldwide, pushing those in poor cotton producing regions deeper into poverty, and so also to work in even worsening conditions. 
control is economic exploitation, that is to say, obtaining benefits from the coerced labour or services (Bales 2000, Kaye and Winterdyk 2012, p. 70).

It must be remembered that the punishment of human trafficking intends to cover a process where a person is recruited and transported with the purpose of some form of exploitation. In this way it is possible to mark the difference between human trafficking for labour exploitation and forced labour: the first one encompasses the process through which one person is recruited and transported (even within national borders) for the purpose of subjecting him/her to coerced labour or services; the second one refers to the coerced work itself, in other words, to the situation of exploitation that in this case consists of working against one's will, under the control of another person. Understanding this difference, it is easy to see that the number of persons subjected to forced labour has to be much higher than the number of persons trafficked for labour exploitation: people coerced to work under external control can be recruited and moved to do this (that is to say, trafficked), or can be dominated in their own place of origin.

Taking this into account, it could be argued if the international emphasis on fighting against human trafficking is the more comprehensive way to end human exploitation, which is really (or should be) the genuine and final objective of this sort of regulations. It is true that trafficking does not require the execution of the exploitative situation, but trafficking being a process, it is necessary to prove all its stages: recruitment, transportation, and purpose of exploitation. It has been stated, not only by authors but by institutional reports (Sanghera 2005, p.14, Olsen 2008, pp. 25-26, Defensor del Pueblo 2012, pp. 55-56), that all these requirements make it really difficult to gather all the evidence and to prosecute the crime; this has led to some collateral consequences: for example, this explains the very low number of prosecutions in national tribunals for the crime of human trafficking; and this has caused States to strengthen their border controls, in order to better combat human trafficking or perhaps to tighten up their migration policy. Another result of this configuration of trafficking is that, due the lack of global evidence of this process, cases of trafficking have been prosecuted as different types of crimes (Defensor del Pueblo 2012, p. 274). All these considerations can lead us to think that more or at least the same emphasis should be put on the prosecution of the crimes that are tantamount to the exploitation itself, instead of focusing mainly on the fight against the trafficking process.

At the same time, the focus on human trafficking for labour exploitation instead on forced labour itself has posed some interpretative problems, and especially due to the developments made by institutional bodies, blurring the limits of these concepts. Human trafficking implies that a person is recruited and transported against his/her will, and one of the means that the UNO recognises to admit this lack of consent is the "abuse of a position of vulnerability". This is a very sore point, because sometimes it is difficult to determine if someone has taken advantage of the vulnerability of another person, 
recruiting and forcing her/him to do some work, or if this person has really chosen to do work in exploitative conditions as the least bad option in her/his vulnerable situation; this issue is especially controversial regarding sex work. The ILO Indicators of human trafficking have included in the indicators of recruitment by abuse of vulnerability the abuse of a difficult family situation, the abuse of illegal status and economic reasons, for example; as the UN document about Abuse of the position of vulnerability (2013) indicates, showing its concern about it, when prosecuting this crime States tend to look for evidence of the position of vulnerability, but not of the "abuse" of this situation. Moreover, the ILO Indicators of human trafficking include similar indicators of abuse of vulnerability at destination, that is to say, in the stage of labour exploitation itself, which poses a difficult compatibility, or even contradiction, with the definition of forced labour, that refers only to work or services made under the threat of a penalty, not the abusing of a position of vulnerability. It is true that the abuse of vulnerability is included by the ILO in its Indicators of forced labour, but the document itself declares that "the mere fact of being in a vulnerable position, for example, lacking alternative livelihood options, does not necessarily lead a person into forced labour. It is when an employer takes advantage of a worker's vulnerable position, for example, to impose excessive working hours or to withhold wages, that a forced labour situation may arise". In any case, it must be remembered that the abuse of the position of vulnerability has to be the way to finally apply control over the worker, and that the concept of forced labour does not include working under hard or exploitative conditions if there is a real possibility of leaving the job without being punished by the employer.

So, a comprehensive fight against human trafficking for labour exploitation would give priority to the prosecution of forced labour itself, even though obviously not disregarding the aspect of trafficking, that is to say, the previous process that looks for the recruitment of people to be coerced to work, which is not always present or necessary in relation to forced labour. An adequate approach to trafficking should not have the tightening of migration policies as a collateral consequence (or as a hidden objective), not only because many cases of trafficking occur within national borders, but also because some restrictive migration provisions could also be a factor that favours trafficking, so that the lack of legal opportunities could facilitate the growth of the trafficking phenomenon (Sanghera 2005, p. 8).

Addressing the factors that lead to forced labour or to human trafficking for labour exploitation is just another important issue that, unfortunately, is neither usually considered nor can be easily tackled. The modification of the current economic capitalist system can really be seen as utopian, characterised by the accumulation of wealth in a small percentage of the global population, and by an industrial production system, that causes the gradual disappearance of subsistence economies and the social solidarity ties inherent to small communities. It has been pointed out that trafficking is favoured by current global 
economic policies, calling for free trade and unqualified jobs promoted by large transnational corporations that purport to offer an unlimited supply of goods and services (Kempadoo 2005, p. XIV). But what can be partially addressed by States or by supranational bodies are the forms and consequences of "offshoring" and the provisions of migration laws, particularly the aspects related to workers' and migrants' rights. And another important factor, not always properly considered, is the role of mass media in the irrational spreading of the supposedly great values of the capitalist and consumer society. Although a great deal of movements of people are really motivated by severe problems like armed conflicts, famine or natural disasters, in other cases the displacement to industrialised countries is driven by high expectations of improving one's life conditions or by the appealing face of the consumer society (Esteva 2001, ACCEM 2008, p. 36, Villacampa 2011, p. 93, Aboso 2013). This question poses two difficult challenges: firstly, the necessity to improve social welfare in some countries (e.g. sanitary or labour conditions), and not only in non - industrialised countries, but also in industrialised States that are now suffering severe cutbacks in this field with hard consequences for the poorest sector of their population; and secondly, the need to make it visible that welfare in rich countries has been achieved mainly thanks to an unfair exploitation of the natural and economic resources of the poorest ones.

\section{Reference list}

ABOSO, Gustavo Eduardo - Trata de personas. La criminalidad organizada en la explotación laboral y sexual. Buenos Aires: B de F, 2013. 245 p. ISBN 9789974708068.

ACCEM - La trata de personas con fines de explotación laboral. Madrid: ACCEM, 2008. 196 p. ISBN 978-84-691-5557-8.

BALES, Kevin - La nueva esclavitud en la economía global. Madrid: Siglo Veintiuno 1999 (translated by F. Borrajo Castanedo, 2000). 322 p. ISBN 9788432310430.

BELSER, P.; ANDREES, B. - Introducción. In ANDREES, B.; BELSER, P. - Trabajo forzoso. Coerción y explotación en el mercado laboral. Madrid: Plaza y Valdés, 2010 (original edition: ILO 2009). ISBN 978-84-92751-91-4. p. 1-16.

BURKE, Mary C. - Introduction to human trafficking: definitions and prevalence. In BURKE, Mary C. - Human trafficking. Interdisciplinary perspectives. New York: Routledge, 2013. ISBN 9781135081850. p. 3-23.

CECCAGNO, A.; RASTELLI, R.; SALVATI, A. - Exploitation of Chinese immigrants in Italy. In YUNG, Gao - Concealed chains. Labour exploitation and Chinese migrants in Europe. Geneva: ILO, 2010. ISBN 978-92-2-121993-4. p. 89-138.

COSTER VAN VOORHOUT, Jill E.B. - 2007. Human trafficking for labour exploitation: interpreting the crime. Utrecht Law Review. ISSN 1871-515X. N ${ }^{\circ} 3(2)$ (2007) p. 44-69. 
COTTINGHAM, Marci et al. - Sociological perspective: underlying causes. In BURKE, Mary C. - Human trafficking. Interdisciplinary perspectives. New York: Routledge, 2013. ISBN 9781135081850. p. 51-72.

DEFENSOR DEL PUEBLO - La trata de seres humanos en España: víctimas invisibles. Madrid: Defensor del Pueblo, 2012. 333 p. ISSN 2254-3910.

DESYLLAS, Moshoula Capous, 2007 - A critique of the global trafficking discourse and U.S. policy. Journal of Sociology \& Social Welfare. Western Michigan University. ISSN 0191-5096. Vol. 34 (2007) p. 1-15.

EHRENREICH, B.; HOCHSCHILD, A.R. - Introduction. In EHRENREICH, B.; HOCHSCHILD, A.R. - Global woman. Nannies, maids and sex workers in the new economy. London: Granta, 2002. ISBN 9781862075887. p. 1-14.

ESTEVA FABREGAT, Claudio, 2001 - Enfoques para una antropología de la migración. Scripta Nova. Revista electrónica de Geografía y Ciencias Sociales. ISSN 11389788. No 94 (1) (2001), p. 1-16.

EU - The EU strategy towards the eradication of trafficking in human beings, 20122016 (Brussels, 19-6-2012, COM(2012) 286 final.

EUROSTAT - Trafficking in human beings. Luxembourg: EU, 2013.

GALLAGHER, Ann - The international Law of human trafficking. New York: Cambridge University Press, 2010. 535 p. ISBN 9780521191074.

GARCÍA VÁZQUEZ, Sonia - La lucha contra la trata de seres humanos a nivel internacional, comunitario y nacional. In GARCÍA VÁZQUEZ, S.; FERNÁNDEZ OLALLA, P. - La trata de seres humanos. Madrid: Centro de estudios políticos y constitucionales, 2012. ISBN 9788425915338. p. 15-97.

GOODEY, Jo - Data on human trafficking: challenges and policy context. In WYINTERDKY, J.; PERRIN, B.; REICHEL, P. - Human trafficking. Exploring the international nature, concerns, and complexities. Boca Raton: Taylor \& Francis Group, 2012. ISBN 9781439820360. p. 39-56.

GRETA - Report concerning the implementation of the Council of Europe Convention on Action against Trafficking in Human Beings by Spain. Strasbourg: Council of Europe, 2013.

IGLESIAS SKULJ, Agustina - Políticas públicas de lucha contra la trata de mujeres en el contexto español: luces y sombras. In IGLESIAS SKULJ, A.; PUENTE ABA, L.M. - Sistema penal y perspectiva de género: trabajo sexual y trata de personas. Granada: Comares, 2012, ISBN 9788498369748. p. 61-80.

ILO - Human trafficking and forced labour exploitation. Guidelines for legislation and law enforcement. Geneva: ILO, 2005. 79 p. ISBN 92-2-117347-X.

ILO - Eradication of forced labour. Geneva: ILO, 2007. 142 p. ISBN 978-92-2-118134-7. 
ILO - Fighting human trafficking, the forced labour dimensions. Vienna: Background paper for the Vienna Forum in Human Trafficking, 2008.

ILO - Operational indicators of trafficking in human beings. Geneva: ILO, 2009.

ILO - Global estimate of forced labour. Executive summary. Geneva: ILO, 2012.

ILO - Hard to see, harder to count. Survey guidelines to estimate forced labour of adults and children. Geneva: ILO, 2012 (2012b). 122 p. ISBN 978-92-2-126172-8.

ILO - Indicators of forced labour. Geneva: ILO, 2012 (2012c).

ILO - Strengthening action to end forced labour. Geneva: ILO, 2013. 111 p. ISBN 97892-2-127751-4.

ILO - Measurement of forced labour. Opportunities and challenges. ILO Special Action Programme to combat Forced Labour. Geneva: ILO, International Conference of Labour Statisticians, 2013 (2013c).

IOM - Human trafficking: new directions for research. IOM, 2008.

KANE, June - Making money out of misery. Trafficking for labour exploitation. In BURKE, Mary C. - Human trafficking. Interdisciplinary perspectives. New York: Routledge, 2013. ISBN 9781135081850. p. 109-132.

KAYE, J.; WINTERDYK, J. -Explaining human trafficking. In WYINTERDKY, J.; PERRIN, B.; REICHEL, P. - Human trafficking. Exploring the international nature, concerns, and complexities. Boca Raton: Taylor \& Francis Group, 2012. ISBN 9781439820360. p. 57-78.

KEMPADOO, Kamala - Introduction. From moral panic to global justice: changing perspectives on trafficking. In KEMPADOO, K.; SANGHERA, J.; PATTANAIK, B. - Trafficking and prostitution reconsidered. New perspectives on migration, sex work, and human rights. Boulder: Paradigm Publishers, 2005. ISBN 1594510970. p. VII-XXXIV.

KEMPADOO, K.; SANGHERA, J.; PATTANAIK, B. - Trafficking and prostitution reconsidered. New perspectives on migration, sex work, and human rights. Boulder: Paradigm Publishers, 2005. 247 p. ISBN 1594510970.

MALPANI, Rohit - La trata de personas como delito y la protección de las víctimas. In ANDREES, B.; BELSER, P. - Trabajo forzoso. Coerción y explotación en el mercado laboral. Madrid: Plaza y Valdés, 2010 (original edition: ILO 2009). ISBN 978-84-9275191-4. p. 139-160.

MAQUEDA ABREU, M ${ }^{a}$ Luisa - Prostitución, feminismos y derecho penal. Granada: Comares, 2009. 176 p. ISBN 9788498365023.

MONTERO, Jerónimo - La moda neoliberal: el retorno de los talleres clandestinos de costura. Geograficando, ISSN 2346 - 898X. No 8 (8) (2012) p. 19-37. 
NELKEN, David - Human trafficking and legal culture. Israel Law Review. ISSN 2047-9336. No 43 (2010) p. 479-513.

O'CONNELL DAVIDSON, Julia - Absolving the State: the trafficking - slavery metaphor. Global Dialogue. No 14(2) (2012) p. 1-11.

OLSEN, Harald Haugom - The snake from Fujian Province to Marecambe Bay: an analysis of the problem of human trafficking in sweated labour. European Journal of Crime, Criminal Law and Criminal Justice. ISSN 1571-8174. No 16 (2008) p. 1-37.

PLANT, Roger - Combating trafficking for labour exploitation: a decent work approach. In OSCE - An agenda for prevention: trafficking for labour exploitation. Vienna: OSCE, 2011. ISBN 978-92-9234-435-1. p. 5-14.

POMARES CINTAS, Esther - El Derecho penal ante la explotación laboral y otras formas de violencia en el trabajo. Valencia: Tirant lo Blanch, 2013. 250 p. ISBN 97892-9234-435-1.

PUENTE ABA, Luz María - La protección frente al tráfico de órganos: su reflejo en el Código penal español. Revista de Derecho y proceso penal. ISSN 1575-4022. No 26 (2011) p. 135-152.

SANGHERA, Jyoti - Unpacking the trafficking discourse. In KEMPADOO, K.; SANGHERA, J.; PATTANAIK, B. - Trafficking and prostitution reconsidered. New perspectives on migration, sex work, and human rights. Boulder: Paradigm Publishers, 2005. ISBN 1594510970. p. 3-24.

SMITH, C.J.; KANGASPUNTA, K. - Defining human trafficking and its nuances in a cultural context. In WYINTERDKY, J.; PERRIN, B.; REICHEL, P. - Human trafficking. Exploring the international nature, concerns, and complexities. Boca Raton: Taylor \& Francis Group, 2012. ISBN 9781439820360. p. 19-38.

TUREK, Jaime M. - Human security and development issues in human trafficking. In BURKE, Mary C. - Human trafficking. Interdisciplinary perspectives. New York: Routledge, 2013. ISBN 9781135081850. p. 73-87.

UNODC - Legislative Guides for the implementation of the United Nations Convention against transnational organised crime and the Protocol thereto. Vienna: UNODC, 2004.

UNODC - Trafficking in persons: global patterns. Vienna: UNODC, 2006.

UNODC - Supply management, eliminating the risks of forced labour and trafficking. Vienna: The Vienna Forum to fight human trafficking, 2008.

UNODC - An introduction to human trafficking: vulnerability, impact and action. Vienna: UNODC, 2008 (2008b).

UNODC - Model Law against trafficking in persons. Vienna: UNODC, 2009.

UNODC - Global report on trafficking in persons. Vienna: UNODC, 2012. ISBN 978-92-1-055896-9. 
UNODC - Abuse of a position of vulnerability and other "means" within the definition of trafficking in persons. Vienna: UNODC, 2013.

UNODC - Global report on trafficking in persons. Vienna: UNODC, 2014. ISBN 97892-1-057108-1.

UNODC - Global report on trafficking in persons. Vienna: UNODC, 2016. ISBN 97892-1-058408-1.

VILLACAMPA ESTIARTE, Carolina - El delito de trata de seres humanos. Una incriminación dictada desde el Derecho internacional. Cizur Menor: Aranzadi, 2011. 598 p. ISBN 9788499038261.

WADE, Marianne - Prosecution of trafficking in human beings cases. In WYINTERDKY, J.; PERRIN, B.; REICHEL, P. - Human trafficking. Exploring the international nature, concerns, and complexities. Boca Raton: Taylor \& Francis Group, 2012. ISBN 9781439820360. p. 153-180.

Artigo Recebido a 11 de abril de 2017 | Aceite a 23 de julho de 2017 
